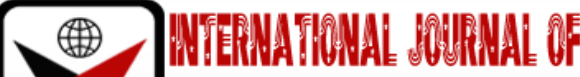

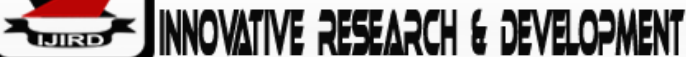

ISSN 2278-0211 (Online)

\section{Internal Versus External Orientation, Which Way for Competitiveness?}

\author{
James Kamau Kairu \\ Ph.D. Candidate, Department of Business Administration, \\ Kenya Methodist University \\ Thomas Anyanje Senaji \\ Professor, School of Business and Management, The East African University \\ Eunice Karegi Kirimi \\ Senior Lecturer, School of Business and Economics, Kenya Methodist University
}

\begin{abstract}
:
Managerial cognition continues to attract interest from researchers in a bid to understand how it relates with performance of organisations. Drawing from the Social Cognitive theory we examine the relationship between managerial orientation (internal/external) and competitiveness of leather and textile firms in Kenya using a descriptive cross-sectional survey of a sample of 163 managers using a structured self-reporting questionnaire. The firms were moderately competitive $(M=3.86, S D=0.40)$ and both internal and external orientation were significantly positively related with competitiveness (internal focus: $r=.465, p=<.001$; external focus: $r=.406, p=<.001$; combined internal/external orientation: $r=.463, p<.001)$. Further, competitiveness was more strongly predicted by internal managerial orientation (Wald $=17.197, p<.001<.05$, exp $(B)=4.777$ ) than external managerial orientation $($ Wald $=1.588, p>.208, \exp (B)=1.575)$. These findings have implications for the resource-based view of the firm which is an internal focus, and on where managers should prioritize actions between internal and external focus in order to achieve competitiveness.
\end{abstract}

Keywords: Managerial orientation, competitiveness, Kenya

\section{Introduction}

Performance of organisations is the focus of strategy. Since managers are charged with the responsibility of guiding organisations in pursuit of the purpose for which the organisations were established, their unique capabilities (e.g., Helfat\& Martin, 2015) are crucial to their success and that of the organisations they manage. One such capability is managerial cognition - how managers perceive and interpret their operating environment and make strategic decisions. It is a crucial management capability with important implications for competitiveness hence performance of organisations. While cognition is about the perceptive process that leads to decision making, competitiveness is efficiency and effectiveness with which the operations of an organization are relative to its close competitors.

\subsection{Competitiveness}

Competitiveness is important the continued existence and survival of firms after their formation. It represents the minimum conditions for firms to remain in the market without implying any kind of competitive advantage. For as long as limits on opportunities and resources exist, firms in any industry have to compete and engage in actions that can give them an advantage over competitors. Competitive actions can take various forms including marketing campaigns, pricing strategies, as well as mergers acquisitions as a growth strategy. The common feature about these activities is that all aim at gaining competitive advantage over rival firms. To gain a better position at the expense of another player in an industry, a firm will resort to effective competitive strategies (Ferrier, 2015).

According to Ocasio (2017) initiation of competitive action by a competitor has consequences to target organization, whose response occurs when decision-makers are aware of the competitor activities. When faced with competitor action, decision-makers' attention focus is guided by two processes. The first one is a bottom-up process that deals with stimuli characteristics and the things that make them unique from others while the top-down process is the second one. This second process is where values, goals, cognitive orientations and required tasks influence the direction of attention. Thomas et al. (2014) argues that in industries experiencing competition at a faster pace, firms in it face a demanding and complex environment, which require managers to develop a quick interpretation of information as a basis for decision and action. This requires appropriate cognitive ability. This interpretation may be a complicated process and various previous research has argued empirically and theoretically that when managers are exposed to the same stimuli, there will be a different interpretation from decision-makers from these organizations. For instance, different managers 
may look at specific competitor action by rivals, with others interpreting it as an opportunity while other see it as a threat. This is due to contextual factors which direct attention, information flow and interpretation (Ocasio, 2017).

In this regard, the more accurate the interpretation of the environment and the use of the information to make decision and take actions, the better will be the performance compared to that of competitors. Consequently, competitiveness should be measured with respect to a benchmark because it is a relative concept (Pedraza, 2014). Thus, firms should be compared with each other, or nations with each other; in this case producing absolute figures for a country or an industry is of no much use with regard to competitiveness. For example, an increase in competitiveness happens when a firm lowers its costs relative to those incurred by rival firms for same or similar product/ service. In this illustration, it is seen that the firm with lower production costs would be more competitive compared to the one with higher production costs.

\subsection{Managerial Orientation}

Internal/external orientations denote the degree to which managers focus their attention on organizational factors, such as employees, systems... (internal orientation) as opposed to the demands and changes in the external environment (eternal orientation) (Walsh, 1995; Donaldson \& Walsh, 2015). It is the tension between internal focus (e.g. Improvement of the efficiency of production and training of staff) and external focus (e.g., focus purchasing power of consumers and competitor actions) which constitutes internal/external orientation.

There may be certain organizational and environmental factors that affect the consideration of managers on the importance they place on external or internal factors (stimuli) while making decisions. For example, on the level of education and experience that offers specific mental schema results in managers' local or foreign market orientation, while attention structure and procedures also guide decision-makers to specific orientation (e.g., Ocasio, 2017). Even though it seems not as stable as other cognitive forms, it is plausible to assume that over a long time these elements crystalize and inform decision making. In particular, that which receives more attention may be more likely to inform decision than that which receives less attention. Further, procedures and norms may also determine the decision that is made because norms of an organization may comprise heuristics which are known to inform most administrative decisions.

Further, construction of the attention which is defined as the economic, cultural and social structure that governs effort, time and attention allocation by the decision-makers of organization are reliable and influence behaviors for a very long (e.g., Hoffman \&Ocasio, 2001; Ocasio, 2011; Ocasio, 2017). These structures of attention are norms that are socially accepted within an organization and guide various activities. In additional to the formation of mental disposition of decision-makers regarding what is right or wrong, and important or not important, the situational factors help in the creation of cognitive schema, which influences subsequent decisions and attention (Ocasio, 2015). The situational factors may be within the organization, including the culture, and physical resources; or outside the organization, such as competition, and new regulations also affect decisions that are made.

Externally oriented managers are more motivated to respond to competitive actions by their competitors. Their likely perceptions are that antecedents for performance of the organization lie in the external environment. This is consistent with the process of strategy discussed in I/O economics and the strategies posited by the position school of thought (see Porter, 1980). The suggestion is that firm performance is highly dependent on how the decision-makers make decisions, the competitive position of the firm in the business and environmental characteristics such as competitors' action and consumer demand. In this approach, managers are highly motivated to respond to environmental changes due to an apparent (perceived) connection to performance.

\subsection{Textile industry in Kenya}

The context of this study was the textile and leather industry in Kenya. Textile industry has been in existence for several years. By the year 1954 there were a total of 74 enterprises in Kenya with 2,477 workers (ACTIF, 2016). After independence, growth of textile industry resulted in local availability of fibers such as cotton, wool and sisal while synthetic fibers (nylon, polyester, acrylics) jute and linen as well as dyes, chemicals, and resins were imported (Kinyanjui, Lugulu \& McCormic, 2004). In mid-1980 the major textile firms in Kenya were Kenya Textile Mills (in Thika), Rift Valley

Textiles (RIVATEX), Mountex (in Nanyuki) and Kisumu Cotton Mills (KICOMI). Production stagnated from mid-80 and fell sharply after liberalization of the sector in the early 90's (Ikiara\&Ndirangu, 2014). In 1984 the policy reform in the Kenyan textile industry started resulting to change of policy to export led industrialization as contained in the national development plan of 1984-88. The policy encouraged export promotion by creating schemes such as Export Processing Zones (EPZs), Manufacturing under Bond (MUB) and Export Compensation Schemes. Markets were liberalized through abolition of quantity restrictions and lowering of tariffs to enable exportation of their products (Kinyanjui et al, 2004).

During the post-independence period textile industry grew rapidly in the immediate due to the protection offered to firms under the import substitution strategy. The investment by the Kenyan government in the industry through Industrial and Commercial Development Corporation (ICDC) also facilitated the growth of the garment and textile industry by locating them in major towns in the country. It also had significant shares in textile firms such as Kenya Textile Mills (Thika), KICOMI (Kisumu), Rivatex (Eldoret) and Mountex (Nanyuki) (ACTIF, 2018).

There were also privately owned textile firms which grew and flourished in the import substitution era. They included among others Yuken, Thika Cloth Mills, United Textile Mills, Sunflag, Spinners and Spinners, and Raymonds. Like other manufacturing, garment firms generally benefited from the protectionist policies which were there up to the mid1980s. As is observed in other manufacturing sectors, the failure by the managers of the textile firms to develop strong vertical and horizontal linkages with other sectors left the firms vulnerable when the protectionist policies were abandoned. One of the garments and textile industries, EPZ, provides an incentive regime for exporting firms in Kenya 
with a 10-year tax holiday, unobstructed foreign ownership and employment in addition to freedom of repatriating unlimited amount of earnings (Kinyanjui et al, 2004).

Today, the textile and leather companies continue to operate in a relatively uncertain environment with stiff competition from imports. Additionally, textile and leather industry policy and regulatory mechanisms aimed at protecting local textile firms from foreign competition are yet to achieve the desired effect. Further, though there is implementation of innovation-driven development strategies in the global textile and leather value chains (see e.g.,Memedovic\&Mattila, 2008), Kenya's textile and leather industry firms have relatively weak innovation capability and are faced with stiff competition both locally and internationally (Kinyanjui et al, 2014) which has affected their performance leading to decline and collapse in some cases.The foregoing conceptual and contextual arguments notwithstanding, there is limited empirical clarity on the relationship between internal/ external orientation and competitiveness of firms. In this paper, we examine the effect of managers' External /Internal orientation on the competitiveness of textile and leather firms in Kenya.

\section{Theory and Hypothesis}

This study was underpinned by the Upper Echelons theory, UET (Hambrick\& Mason, 1984) that hypothesizes that the outcomes of organizations are predicted partially by the characteristics of the managers at the top position of an organization and the Social Cognitive Theory, SCT (Bandura, 1986) which explains psychosocial operational processes in terms of causation of triadic reciprocal. In this theory, behaviour, cognitive and casual structure, and other factors of individual together with environmental events function as interacting factors that influence each other in a bi-directional manner.

\subsection{Upper Echelon Theory}

The UET attributes decision makers to behavioural factors rather that objectives and clear economic optimization. This theory plays an important role during decision making by the Top Management Team (TMT). The theory posits that the strategy of an organization is a reflection TMT thought. This theory underpins TMT decisions including how they allocate attention and deal with competitive dynamics. This theory may suffer some limitations because the current thinking in organisations is the empowerment of middle managers to make decisions and act quickly because it is at this level of management where critical actions are to be taken. It would therefore appear that the notion of 'behaviour of an organization being the refection of TMT may not be entirely sufficient because the lower-level managers play an equally crucial role in the overall outlook/ performance of the organization.

\subsection{Social Cognitive Theory}

On the other hand, the SCT posits that the cognitive and behavioural aspects influence of managerial decision making. The theory is important because it creates a link between an individual's cognitive structure and the decisions, they make regarding strategy formulation and implementation.

In general, both UET and SCT underpin managerial cognition which is at the core of managers' disposition with regard to salience, regulatory focus, identity domain and external/internal orientation which in turn affect their strategic posture and performance. The predictions of the SCT notwithstanding, it is important to consider the fact that cognitions are subject to individual biases which may impair the accuracy of these cognitions and the decisions that arise from them.

It is also possible that managers differ in their cognitive complexities and therefore the heterogeneity in their decisions.

Based on the forgoing theoretical review, it was hypothesized that:

- $\mathrm{H}_{0}$ : Managers' External /Internal Orientation has no significant influence on the competitiveness of textile and leather firms in Kenya.

- Specifically,

- $\mathrm{H}_{01}$ : Internal orientation has no significant influence on competitiveness of leather and textile firms in Kenya

- $\mathrm{H}_{02}$ : External orientation has no significant influence on competitiveness of leather and textile firms in Kenya

\section{Methodology}

\subsection{Design}

A descriptive survey research of textile and leather manufacturing firms listed by Kenya Association of Manufacturers (KAM)was conducted.

\subsection{Sample}

The sampling frame for this study was top level managers from all the 104 firms (textile and apparels: $\mathrm{N}_{1}=85$; leather and footwear: $\mathrm{N}_{2}=19$ ) in Kenya as listed by KAM (KAM, nd.). These firms were distributed throughout Kenya. Since the unit of analysis was the firm, one respondent per firm with the right information regarding the operations of the firm would have sufficed, however since the study was about cognitions which vary across individuals, at least three responses from managers were targeted from each firm. A total of 163 responses were received from these firms.

\subsection{Measures of Variables}

Orientation is a cognitive disposition of an individual which determines whether the focus on factors that are within their organization (internal) or factors that are outside their organization (external orientation) which have implications for business. In order to assess this construct - external/ internal orientation - two sets of indicators, one for 
internal orientation comprising two indicators and the other for external orientation with four indicators were used to assess leather and textile managers' orientation. Consequently, they were asked to think about their businesses for the last one to three years and indicate the frequency with which they paid attention to and acted on the internal and external orientation indicators. They responded with either 'Never', 'Rarely', 'Sometimes', 'Often' or 'Always' with Never = 1 and Always $=5$. The respondents provided responses to two indicators of internal orientation, namely 'Improvement of the efficiency of production' and 'Improving communication within the business'In a similar manner, external orientation was measured using four indicators by asking the respondents to indicate the frequency with which they paid attention to and acted upon four factors: purchasing power of consumers, consumer tastes, competitor actions and government policy in their business decisions.

\subsection{Instruments and Data Collection Procedures}

The data collection instrument was a structured questionnaire which was tested for reliability (e.g., Fink, 1995) and the results are present in the leading diagonal of the correlation results table (Table 3 ). All measures met the threshold Cronbach alpha value of at least 0.6 which is acceptable for new a measurement instrument such as the one that was used in this study.

Variable item measures were anchored on a five-point Likert scale. Self-administered structured questionnaires were distributed online using google forms to three managers in each of the 104 textile and leather manufacturing firms.

\subsection{Data Analysis}

Data was processed using the SPSS (Statistical data processing for Social Sciences) version 24and binary logistic regression used to estimate the effect of in/external orientation on competitiveness (dependent variable) since it elicited ordinal level responses. The dependent variable was binary coded according to the following rule

$$
y *= \begin{cases}1, \text { if } y=\operatorname{TRUE}(y=>3.4) \\ 0, \quad \text { otherwise }(y<3.4)\end{cases}
$$

Where $\mathrm{y}^{*}$ is a binary variable which takes a value of ' 1 ' for an aggregate mean equal to or more than $3.4(y=>3.4)$ and ' 0 ' for a value of $y$ (mean) less than $3.4(\mathrm{y}<3.4)$ on a scale of 1 to 5 where $1=$ Almost Never True, and $5=$ Almost Always True

Upon binary coding of 'competitiveness' responses from five-point Likert scale responses to binary, logistic regression was performed where managerial cognition variable, namely external and internal orientation were used to predict the odds for competitiveness (see Model 1)thus:

Model 1: Effect of managerial orientation on competitiveness of firms Logit $L=\ln \left(\frac{p}{1-p}\right)=\mathrm{z} ;$ where $\mathrm{z}=\beta_{0}+\beta_{1} X_{1}+\beta_{2} X_{2}+\varepsilon$

WhereL= logit for firm competitiveness, $\beta_{0}=$ constant, $\beta_{i}(i=1,2)$ are the regression coefficients associated with managerial cognition variables and $X_{i}(i=1,2)=$ independent variables (internal orientation and external orientation); $\mathrm{z}=$ log of the odds for firm competitiveness which is expressed as linear combination of independent variables, Xi, $\varepsilon=$ error term assumed to be normally distributed with zero mean and constant variance.

\section{Results and Discussion}

The results of the data analysis comprising reliability of instruments, descriptive results, correlations, association between pairs of variables and logistic regression results for the influence of managerial orientation (internal and external orientation) on competitiveness of leather and textile firms in Kenya are presented and discussed.

\subsection{Status of Internal/ External Orientation and Competitiveness}

The descriptive results are presented in Table 1.

\begin{tabular}{|c|c|c|c|c|c|c|c|}
\hline & $\mathbf{N}$ & $\mathbf{M}$ & $\mathbf{S D}$ & \multicolumn{2}{|c|}{ Skewness } & \multicolumn{2}{c|}{ Kurtosis } \\
\hline & Stat. & Stat. & Stat. & Stat. & SE & Stat. & SE \\
\hline $\begin{array}{c}\text { Improvement of the efficiency of production } \\
\text { Improving communication within the } \\
\text { business }\end{array}$ & 160 & 4.55 & 0.75 & -2.024 & 0.192 & 5.181 & 0.381 \\
\hline $\begin{array}{c}\text { Internal orientation } \\
\text { Imarchasing power of consumers }\end{array}$ & 162 & 4.67 & 0.69 & -1.894 & 0.191 & 4.247 & 0.380 \\
\hline Consumer tastes & 162 & 4.30 & 0.90 & -2.011 & 0.191 & 5.162 & 0.379 \\
\hline Competitor actions & 161 & 4.57 & 0.70 & -1.764 & 0.191 & 3.814 & 0.379 \\
\hline Government policy & 161 & 4.55 & 0.77 & -1.890 & 0.191 & 3.741 & 0.380 \\
\hline External orientation & 162 & 4.37 & 0.68 & -1.342 & 0.191 & 3.891 & 0.379 \\
\hline Internal/External Orientation & 162 & 4.44 & 0.65 & -1.008 & 0.191 & 1.140 & 0.379 \\
\hline Valid N (listwise) & 157 & & & & & & \\
\hline
\end{tabular}

Table 1: Status of Internal and External Orientation 
These results imply that that the managers' decisions were more internally oriented than they were externally oriented (Internal orientation: $\mathrm{M}=4.55, \mathrm{SD}=0.75$; External orientation: $\mathrm{M}=4.37, \mathrm{SD}=0.68$ ). The aspect that they considered and acted upon most was consumer tastes and government policy (external) while they also frequently considered and acted upon two internal conditions, namely 'Improvement of the efficiency of production' ( $\mathrm{M}=4.55)$ and 'Improving communication within the business' $(\mathrm{M}=4.60)$. From a managerial cognition perspective, this result suggests that there was sufficient practice of internal/external orientation by textile ad leather firms' managers in Kenya ( $\mathrm{M}=4.44$, $\mathrm{SD}=0.65$ ). This means that the managers pay attention to both internal and external conditions while making decisions and operating their businesses. Specifically, a mean of between 4 and 5 on both external and internal orientation, as was the case in this study, indicated that they 'often' and always paid attention to and acted upon perception of the two categories of factors (both internal and external) in their decisions and business operations.

\subsection{Competitiveness}

Assessment of competitiveness of the studied firms was done using both effectiveness and efficiency indicators: six effectiveness and nine efficiency measures. Specifically, the respondents were asked to think of their business during the 'last one to three years' and indicate the extent to which the provided statements that were used to measure competitiveness were true about their business. The possible responses were: 'Almost Never True = 1', 'Usually Not True $=2$ ', 'Occasionally True' = 3, 'Usually True' = 4, and 'Almost Always True' $=5$. The result of the analysis of the collected is presented in Table 3.

\begin{tabular}{|c|c|c|c|c|c|c|c|}
\hline \multicolumn{8}{|c|}{ Descriptive Statistics } \\
\hline \multirow{2}{*}{ Effectiveness } & \multirow[t]{2}{*}{$\mathbf{N}$} & \multirow[t]{2}{*}{$\mathbf{M}$} & \multirow[t]{2}{*}{ SD } & \multicolumn{2}{|c|}{ Skewness } & \multicolumn{2}{|c|}{ Kurtosis } \\
\hline & & & & & & & \\
\hline Increased our market share & 159 & 3.97 & 0.87 & -0.587 & 0.192 & 0.042 & 0.383 \\
\hline Increased profitability & 159 & 4.06 & 0.90 & -0.644 & 0.192 & -0.218 & 0.383 \\
\hline $\begin{array}{c}\text { Increased the number of } \\
\text { branches/Sister firms in the same } \\
\text { geographical area }\end{array}$ & 158 & 2.93 & 1.43 & -0.142 & 0.193 & -1.369 & 0.384 \\
\hline $\begin{array}{l}\text { We have maintained a price slightly } \\
\text { lower than our competitors }\end{array}$ & 161 & 3.37 & 1.03 & -0.193 & 0.191 & -0.601 & 0.380 \\
\hline $\begin{array}{c}\text { Expanded into new geographical } \\
\text { markets }\end{array}$ & 160 & 3.49 & 1.25 & -0.633 & 0.192 & -0.488 & 0.381 \\
\hline $\begin{array}{l}\text { Significantly reduced the cost of our } \\
\text { operations (cos) }\end{array}$ & 156 & 3.63 & 1.05 & -0.498 & 0.194 & -0.325 & 0.386 \\
\hline Aggregate score (effectiveness) & & 3.57 & 0.41 & & & & \\
\hline Efficiency & & & & & & & \\
\hline $\begin{array}{l}\text { Improved our customer satisfaction } \\
\text { levels (cr) }\end{array}$ & 162 & 4.28 & 0.85 & -1.181 & 0.191 & 1.210 & 0.379 \\
\hline $\begin{array}{l}\text { Made improvements on existing } \\
\text { products (ino) }\end{array}$ & 159 & 4.20 & 0.88 & -1.203 & 0.192 & 1.564 & 0.383 \\
\hline Commercialized new products (ino) & 159 & 3.94 & 1.00 & -0.939 & 0.192 & 0.891 & 0.383 \\
\hline $\begin{array}{l}\text { Our quality is better than that of our } \\
\text { competitors (qual) }\end{array}$ & 158 & 4.44 & 0.69 & -0.945 & 0.193 & 0.139 & 0.384 \\
\hline $\begin{array}{c}\text { We have implemented system that } \\
\text { have increased our knowledge } \\
\text { about the market requirements } \\
(\mathrm{kno})\end{array}$ & 161 & 3.89 & 0.95 & -0.732 & 0.191 & 0.465 & 0.38 \\
\hline $\begin{array}{l}\text { We have expanded our community } \\
\text { services (sr) }\end{array}$ & 155 & 3.67 & 1.18 & -0.682 & 0.195 & -0.260 & 0.387 \\
\hline $\begin{array}{l}\text { We have forged beneficial strategic } \\
\text { alliances (sa) }\end{array}$ & 157 & 3.67 & 1.21 & -0.715 & 0.194 & -0.319 & 0.385 \\
\hline $\begin{array}{l}\text { Our production techniques have } \\
\text { been enhanced (prod) }\end{array}$ & 156 & 4.10 & 0.97 & -0.862 & 0.194 & -0.047 & 0.386 \\
\hline $\begin{array}{l}\text { Efficiency of our operations have } \\
\text { been improved through } \\
\text { implementation of information and } \\
\text { communication technologies (ict) }\end{array}$ & 159 & 4.24 & 0.88 & -0.937 & 0.192 & -0.003 & 0.383 \\
\hline Aggregate score (efficiency) & & 4.04 & 0.27 & & & & \\
\hline Competitiveness Score & & 3.86 & 0.40 & & & & \\
\hline Valid N (listwise) & 160 & & & & & & \\
\hline
\end{tabular}

Table 2: Competitiveness of Leather and Textile Firms in Kenya

Key: $\operatorname{Cos}=$ Cost Ino = Innovation, Sr=Social Responsibility, Cr = Customer Relations, Prod $=$ Product Innovation, Kno =

Knowledge Management, Ict = Adoption of Technology, Qual=Quality of Products, Sa = Strategic Alliances 
This result (Table 2) suggests that the firms were more efficient than they were effective because the aggregate mean for effectiveness measures was below $4.00(\mathrm{M}=3.57, \mathrm{SD}=0.41)$ while that of efficiency measure of competitiveness was more than $4.00(\mathrm{M}=4.04, \mathrm{SD}=0.27)$. This result also suggests that the leather and textile firms were moderately competitive in their business. These results also show that the leather and textile firms in Kenya had enhanced their effectiveness through increased our market share $(M=3.97, S D=0.87)$, increased profitability $(M=4.06, S D=0.90)$, and through significant reduction of the cost of operations (Cost: $M=3.63$, SD $=1.05$ ) of these firms.

In addition, the efficiency indicators of competitiveness were that 'customer satisfaction levels had increased' (customer relations: $\mathrm{M}=4.28, \mathrm{SD}=0.85$ ), 'Made improvements on existing products' (Innovation: $\mathrm{M}=4.20, \mathrm{SD}=0.88$ ), and that 'Our quality is better than that of our competitors' (Quality: $M=4.44, \mathrm{SD}=0.69$ ). Further, the forms' production techniques had been enhanced (Product: $\mathrm{M}=4.10, \mathrm{SD}=0.97$ ), and that 'Efficiency of our operations have been improved through implementation of information and communication technologies' (ICT implementation: $\mathrm{M}=4.24, \mathrm{SD}=0.88$ )

According to Roman, Piana, Pereira, Lozano, de Mello \&Erdmann (2012, p. 25), organizational competitive factors are: 'strategic alliances, human capital, reliability, knowledge, cost, cultural factors, flexibility, innovation, quality, speed, customer relations, social responsibility, control systems, production techniques, and information and communication technologies'. In this study, factors related to cost, innovation, quality, social responsibility, knowledge, and customer relations, strategic alliances, production techniques, and information and communication technologies deployments for efficiency improvements were measured. The results of this study suggest that the leather and textile firms were only moderately competitive $(\mathrm{M}=3.86, \mathrm{SD}=.40)$

\subsection{Relationship between Orientation and Competitiveness}

Orientation was measured with two indicators for internal orientation and four indicators from eternal orientation. The relationship between orientation and competitiveness of was assessed using correlations analysis of the composite scores of internal orientation, external orientation and competitiveness which also had two categories of measures (effectiveness and efficiency). The result is presented in Table 3.

\begin{tabular}{|l|l|l|l|l|l|l|}
\hline \multicolumn{1}{|c|}{ Correlations } & & & & & & \\
\hline & $\mathrm{M}$ & \multicolumn{1}{|c|}{$\mathrm{SD}$} & \multicolumn{1}{|c|}{1} & 2 & \multicolumn{1}{|c|}{3} & 4 \\
\hline 1. Internal orientation & 4.57 & 0.68 & 0.619 & & & \\
\hline 2. External orientation & 4.37 & 0.68 & $.506^{* *}$ & 0.855 & & \\
\hline 3. Internal/external orientation & 4.44 & 0.65 & & & 0.636 & \\
\hline 4. Competitiveness & 3.86 & 0.40 & $.465^{* *}$ & $.406^{* *}$ & $.463^{* *}$ & 0.809 \\
\hline & & & 161 & 161 & 161 & 163 \\
\hline
\end{tabular}

Table 3: Relationship between Orientation and Competitiveness

** Correlation is Significant at the 0.01 Level (2-Tailed)

As seen from Table 3, the reliability of the data collection instrument (questionnaire) was assessed using. The Cronbach alpha reliability results are presented in the leading diagonal (Internal orientation: $\alpha=0.619$; External orientation: $\alpha=0.855$; Internal/external orientation: $\alpha=0.636$; Competitiveness: $\alpha=0.809$ ). Therefore, instrument was reliable for measuring the variables because the Cronbach alpha was at least 0.6 which is acceptable for new data collection instruments (e.g., Hair et al., 2010). Internal orientation had a stronger positive influence on competitiveness compared to external orientation (internal: $r=.465, p<.05$; external: $r=.406, p<.05$ ) while the orientation (internal/ external) also had a positive significant relationship with competitiveness of leather and textile firms in Kenya. Consequently, managerial orientation (internal/ external) of managers has important implications for competitiveness and more attention should be directed to internal factors compared to external factors.

\subsection{Influence of Orientation on Competitiveness}

While the measures for internal orientation were improvement of the efficiency of production and improving communication within the business, those for external orientation were attention to' purchasing power of consumers', 'consumer tastes', 'competitor actions', and 'government policy'.

The composite mean of responses on competitiveness (dependent variable) were binary coded as TRUE $=1$ and NOT TRUE $=0$. Consistent with the categorization of responses, 'Almostnevertrue', and'Usually not true', were coded '0' while'Usually true' and'Almost always true'responses were coded as ' 1 '. Based on this data transformation for competitiveness, and using composite scores of internal and external orientation as independent variables, a logit was estimated and the results are presented in Table 4. 


\begin{tabular}{|c|c|c|c|c|c|c|c|c|}
\hline \multicolumn{2}{|c|}{ Model Summary } & \multirow{2}{*}{\multicolumn{3}{|c|}{ Cox \& Snell R Square }} & \multirow{2}{*}{\multicolumn{4}{|c|}{ Nagelkerke R Square }} \\
\hline Step & -2 Log likelihood & & & & & & & \\
\hline 1 & $152.749^{a}$ & \multicolumn{3}{|c|}{0.210} & \multicolumn{4}{|c|}{0.303} \\
\hline \multirow{2}{*}{\multicolumn{9}{|c|}{$\begin{array}{c}\text { a Estimation terminated at iteration number } 5 \text { because parameter estimates changed by less than } .001 . \\
\text { Classification Tablea }\end{array}$}} \\
\hline & & & & & & & & \\
\hline & \multicolumn{2}{|l|}{ Observed } & \multicolumn{3}{|c|}{ Predicted } & \\
\hline & & & \multicolumn{3}{|c|}{ Competitiveness_bin } & & & \\
\hline & & & \multicolumn{2}{|c|}{$\mathbf{0}$} & 1 & \multicolumn{3}{|c|}{ Percentage Correct } \\
\hline Step 1 & Competitiveness_bin & 0 & \multirow{2}{*}{\multicolumn{2}{|c|}{$\frac{13}{7}$}} & 32 & \multicolumn{3}{|c|}{28.9} \\
\hline & & 1 & & & 109 & \multicolumn{3}{|c|}{94.0} \\
\hline & \multicolumn{2}{|c|}{ Overall Percentage } & & & & \multicolumn{3}{|c|}{75.8} \\
\hline \multicolumn{9}{|c|}{ a The cut value is .500} \\
\hline \multicolumn{9}{|c|}{ Coefficients Variables in the Equation } \\
\hline & & $\mathrm{B}$ & S.E. & Wald & & Df & Sig. & $\operatorname{Exp}(\mathrm{B})$ \\
\hline \multirow[t]{3}{*}{ Step $1^{\mathrm{a}}$} & Internal orientation & 1.564 & 0.377 & 17.197 & & 1 & $<0.001$ & 4.777 \\
\hline & External orientation & 0.455 & 0.361 & 1.588 & & 1 & 0.2080 & 1.575 \\
\hline & Constant & -8.059 & 1.817 & 19.663 & & 1 & $<0.001$ & 0 \\
\hline \multicolumn{9}{|c|}{ a. Variable(s) entered on step 1: Internal, External. } \\
\hline
\end{tabular}

The Negelkerke Pseudo $\mathrm{R}^{2}$ suggests that the estimated $\mathrm{R}^{2}$ is 0.303 which means that internal/external orientation may explain slightly over $30 \%$ in improvement of the changes of competitiveness of the leather and textile firms. Further, according to the coefficients table, internal orientation significantly (Wald $=17.197, \mathrm{p}<.001<.05$ ) increased the odds for competitiveness by a factor of about $5(\exp (B)=4.777)$ while external orientation increased the odds by a factor of at least $1.5(\exp (B)=1.575)$ but this increase was not significant. Overall, this logistic regression result suggests that orientation positively influences the odds for firm competitiveness and that internal orientation had a greater influence compared to external orientation.

While externally oriented managers are more motivated to respond to competitive actions by competitors, internally oriented ones focus on how internal factors - employees, finances, technology, culture can be improved to enable the organization compete more effectively. For the latter category the perceptions are that antecedent for the performance of the organization are factors (or cues) that lie inside the organizationrather than in the external environment as the case for the former. In the context of external orientation, managers are highly motivated to respond to environmental changes due to an apparent (perceived) connection to performance. On the other hand, internal orientation is grounded in the capability paradigm where organisations need to developed capabilities related to processes this improving efficiency of service to customers and operational efficiency (Helfat\& Martin, 2015).

\section{Conclusion and Implications}

Based on the findings of this study, there is moderate competitiveness $(M=3.86, S D=0.40)$ both leather and textile firms in Kenya. The studied firms were more internally oriented than they are externally oriented though this difference was not statistically significant at $\mathrm{p}<.05$.

It was hypothesized that: 'Managers' external/internal orientation has no significant influence on the competitiveness of textile and leather firms in Kenya.' However, managerial internal/external orientation had a significant relationship with competitiveness of leather and textile firms in Kenya. In particular, both external orientation and internal orientation are positively and significantly related with competitiveness. However, internal orientation has a stronger effect on competitiveness than external orientation (internal: $r=.465, \mathrm{p}<.05$; external: $\mathrm{r}=.406, \mathrm{p}<.05$ )).

Further, internal managerial orientation had a significant influence on the odds for competitiveness while external orientation did not. Specifically,competitiveness was more predicted by internal managerial orientation (Wald $=17.197, \mathrm{p}$ $<.001<.05$, exp $(B)=4.777)$ rather than external managerial orientation $($ Wald $=1.588, p>.208$, exp $(B)=1.575)$. These findings have implications that managers should prioritize their actions between internal and external orientation in order to achieve the desired results. In particular, focusing on two internal factors, namely improvement of the efficiency of production and on improving communication within the business would enhance the competitiveness of leather and textile firm in Kenya. Further, an external orientation targeting on consumer tastes and government policy would aid in enhancing competitiveness. In addition, the competitiveness of the leather and textile industry firms can be improved by managers constructing and adoption appropriate orientations.

\section{References}

i. Bandura, A. (1986). Social foundations of thought and action: A social cognitive theory. Englewood Cliffs, NJ: Prentice-Hall.

ii. Cooper, R.D., \& Schindler, P.S. (2016). Business Research Methods. (8 ${ }^{\text {th }}$ ed.). New Delhi: Tata McGraw-Hill Edition.

iii. Fink, A. (1995). How to measure survey reliability and validity (Vol. 7)? Thousand Oaks, CA: Sage Publications.

iv. Hambrick, D. C. \& Mason, P. A. (1984). Upper Echelons: The Organization as a Reflection of Its Top Managers. Academy of Management Review, 9(2), 193-206. 
v. Helfat, C. E., \& Martin, J. A. (2015). Dynamic managerial capabilities: Review and assessment of managerial impact on strategic change. Journal of Management, 41(5), 1281- 1312.

vi. Hoffman, A. J., \&Ocasio, W. (2001). Not All Events Are Attended Equally: Toward a Middle-Range Theory of Industry Attention to External Events. Organization Science, 12(4), 414-434.

vii. KAM (n.d.). Textile and Apparels Sector. Retrieved May 22, 2020 from http://directory.kam.co.ke/index.php/textile-apparels-sector

viii. Kinyanjui, M., Lugulu, P., \&McCormic, D. (2004). Clothing and Footwear in Kenya: Policy and Research Concerns. In Clothing and Footwear in Africa. African Institute of South Africa

ix. Memedovic, O., \&Mattila, H. (2008). The global leather value chain: the industries, the main actors and prospects for upgrading in LDCs. International Journal of Technological Learning Innovation and Development, 1 (4), 482519. DOI: 10.1504/IJTLID.2008.021965

x. Ocasio, W. (2011). Attention to Attention. Organization Science, 22(5), 1286-1296.

xi. Ocasio, W. (2017). Towards an Attention-Based View of the Firm. Strategic Management Journal, 18(Special), 187-206.

xii. Pedraza J. M. (2014 March). 'How to evaluate competitiveness? Which economic indicators can we use for the evaluation of competitiveness of agricultural food companies?' Retrieved June 23, 2020 from https://www.researchgate.net/post/How_to_evaluate_competitiveness_Which_economic_indicators_can_we_use _for_the_evaluation_of_competitiveness_of_agricultural_food_companies

xiii. Roman, D. J., Piana, J., Pereira, M-A. S., Lozano, L., de Mello, N. R., \& Erdmann, R. H. (2012). Organizational competitiveness factors, Brazilian Business Review, 9 (1), 25-42 ISSN 1808-2386. Retrieved April 26, 2020 from https://www.researchgate.net/publication/287397840

xiv. Walsh, J. P. (1995). Managerial and Organizational Cognition: Notes from a Trip Down Memory Lane. Organization Science, 6(3), 280-321. 